\title{
1. Protecting labour rights in a globalizing world: an introduction
}

\author{
Axel Marx, Jan Wouters, Laura Beke and \\ Glenn Rayp
}

Stories and images of collapsed factories, burned down sweatshops, imprisoned migrant workers, abused child workers, violent suppression of peaceful labour protests and many other violations of internationally recognized labour rights continue to spread across the globe. This is nothing new. Nor is the recognition that addressing these issues is not the sovereign and sole responsibility of a state. Many labour rights violations take place in the context of transnational and global economic transactions, and there has long been a widespread consensus that international action and coordination are necessary to address labour rights violations. International labour regulation, as a result, has a long history. Attempts to internationally coordinate the improvement of labour conditions date back from 1919, when the International Labour Organization (ILO) was established to develop international policies and norms on a range of labour-related issues. Since its creation in 1919, The International Labour Organization (ILO) has introduced a system of international labour standards aimed at "promoting opportunities for women and men to obtain decent and productive work, in conditions of freedom, equity, security and dignity'. ${ }^{1}$ The basic idea, in 1919, was to prevent a deterioration of labour standards and promote their adoption in a world recovering from war, based on the principle of social justice as an indispensable condition for universal and lasting peace', ${ }^{2}$ whereby 'the failure of any nation to adopt humane conditions of labour is an obstacle in the way of other nations which desire to improve the conditions in their own countries'. ${ }^{3}$ The latter specifically referred to the increase in volumes of trade and the resulting international

1 See: http://www.ilo.org/global/standards/introduction-to-international-labourstandards/lang--en/index.htm

2 First Recital of the Preamble, ILO Constitution.

3 Third Recital of the Preamble, ILO Constitution. 
economic competition which was intensifying between countries in the context of rapid industrial development. This competition led some countries to pursue a strategy of either not installing or lowering labour standards to gain a competitive advantage in producing goods, since the protection of labour standards was assumed to increase production costs.

The need to balance the benefits from international trade and investment with the protection of workers was further developed in the ILO's Philadelphia Declaration, which was adopted in 1944 and annexed to the 1919 Constitution. The Declaration aimed to balance trade and labour concerns and over time has led to the adoption of many labour-rightsrelated conventions within the context of the ILO. So far, the ILO has put forward 189 conventions, six protocols and 203 recommendations, ${ }^{4}$ and has consistently promoted four core labour standards since the adoption of the 1998 Declaration on Fundamental Principles and Rights at Work. This Declaration on Fundamental Principles and Rights at Work covers the core rights and standards laid down in four principles and eight conventions. These principles are: (1) freedom of association and the effective recognition of the right to collective bargaining; (2) elimination of all forms of forced or compulsory labour; (3) effective abolition of child labour; and (4) elimination of discrimination and respect for employment and occupation. As stipulated by the ILO the 'Declaration makes it clear that these rights are universal, and that they apply to all people in all States - regardless of the level of economic development'. ${ }^{5}$

Testifying to its scaling-up efforts not only to advance ratification but also to foster the effective enforcement of core labour standards in its 185 member states, the ILO adopted its Declaration on 'Social Justice for a Fair Globalization' in 2008, promoting the decent work agenda and stressing the 'need for a strong social dimension to globalization' (ILO, 2008, p. 1). This was again emphasized in the 2010 Action Plan (ILO, 2009, p. 1). In addition, other intergovernmental initiatives were developed to further promote the protection of labour rights through addressing multinational enterprises. These include, for example, the ILO Tripartite Declaration of Principles concerning Multinational Enterprises and Social Policy (MNE Declaration) and the OECD Guidelines for Multinational Enterprises. The MNE Declaration, adopted by the ILO's Governing Body in 1977, is currently laid down in its fourth edition of 2006. The Declaration tries to

4 http://www.ilo.org/dyn/normlex/en/f?p=NORMLEXPUB:1:0, accessed on 7 March 2015.

5 See http://www.ilo.org/declaration/thedeclaration/lang--en/index.htm, accessed on 7 March 2015. 
encourage MNEs to participate in creating economic and social welfare and highlights the role which firms play in safeguarding labour and human rights. The OECD Guidelines for Multinational Enterprises were adopted in 1976 and updated for the fifth time in 2011. The OECD Guidelines provide for a global framework for responsible business conduct, covering areas such as human rights, employment and industrial relations, environment, combating bribery, consumer protection, science and technology, competition and taxation. Finally, the United Nations Global Compact (the Compact), launched on 26 July 2000, aims to bring together a wide variety of stakeholders, including civil society organizations, trade unions and academic scholars, in order to enable businesses to pursue a corporate social responsibility agenda based on ten principles, including human rights declarations, labour rights declarations, environment declarations and the anti-corruption convention.

However, confronted with many labour rights violations across the world, despite the widespread ratification of ILO conventions, the World Bank (2012, pp.32-33) recently expressed the concern that 'ratification on its own is not sufficient'. Indeed, many academic scholars have focused on the so-called 'enforcement' and 'compliance gap', showing that ratification of international conventions is not a sufficient condition for compliance. Hafner-Burton (2013, p. 3) plots for nine protected rights under the UN Covenant on Civil and Political Rights, the number of states which have ratified the Covenant and, for those states who have ratified the Covenant, the number of states in which there are reported violations of these rights or which are known to abuse those rights. The analysis shows that for worker rights the number of states which abuse workers' rights is almost as high as the number of states which have ratified the Covenant, indicating that for almost every state which has ratified the Covenant there are still abuses. Beth Simmons $(2009,2013)$ also identified this compliance gap and so-called false positives, i.e. countries which ratify international treaties without the intention of really enforcing them. Recognizing the limits of multilateral enforcement through international agreements, several state and non-state actors have developed a range of policy tools which aim to enforce compliance with labour rights.

These initiatives have proliferated through the last decade and take many forms. Most notably, labour rights are increasingly governed through a variety of unilateral and bilateral governmental initiatives and via different non-state initiatives. Over recent years these initiatives have received increasing attention in the literature. These include: the integration of labour rights in the unilateral (Yap, 2013) and bilateral trade policies (ILO, 2013) of governmental actors; the rise of unilateral action by firms in the form of corporate social responsibility (Vogel, 2005); the 
conclusion of International Framework Agreements between multinational enterprises and global union federation (Niforou, 2012) and the emergence of non-state regulatory initiatives which monitor and enforce labour rights (Marx and Wouters, 2015; forthcoming). This volume aims to take stock of these developments, map the different initiatives, assess the current forms they take, and highlight the potential and limitations of these forms of global labour governance.

\section{OUTLINE OF THE BOOK}

The volume starts off with an empirical contribution on the evolution of the protection of two fundamental labour rights and rights which are generally considered to be two key enabling rights for other rights, namely freedom of association and collective bargaining. Marx, Soares and Van Acker build on the work of David Kucera $(2001,2002)$ and Layna Mosley (2011) to analyse the protection of the rights of freedom of association and collective bargaining in 73 countries over 30 years. Their chapter offers new empirical evidence that the protection of these rights has declined over the last three decades. The decline is less marked for OECD countries, but even in these countries one can observe a decline in the protection of these rights, based on an index which takes 37 items into account. The authors extensively discuss the main results and delve deeper into the possible explanations for this decline. Their contribution shows that despite the commitment, through ratification, of many countries to these two international ILO conventions, these rights are increasingly not protected - quite the reverse. A similar analysis is not available for many other labour rights since the data is lacking. As the authors show, the existing human rights indicators are only a weak proxy to measure the protection of labour rights. Without extrapolating these results to other labour rights it is safe to assume that the protection of labour rights is under stress. Consequently several state and non-state initiatives are developed to further strengthen the enforcement of labour rights. The other contributions in this volume focus on these initiatives.

A first set of chapters concentrates on the governance of labour rights through trade. Non-trade objectives, such as the protection of labour rights, are increasingly pursued through trade policies. This shift to the use of trade as a policy instrument has received scholarly attention in recent times. In an early contribution, Meunier and Nicolaïdis (2006) coined the idea of governing through trade in reference to external relation policies pursued by the European Union (EU). Governing through trade refers to the fact that the EU uses inter alia its trade policy to 'export' its laws, 
standards, values and norms. This governing through trade can take many forms, including via regulatory measures, unilateral trade measures and/or bilateral trade agreements (for an elaborate discussion see Wouters et al., 2015). Samantha Velluti in 'The EU's Social Dimension and its External Trade Relations' provides a comprehensive discussion of how the EU uses its Common Commercial Policy (CCP) to pursue non-trade objectives. She argues that by injecting a normative approach into its external relations through Articles 3(5) and 21 of the Treaty on the European Union, the EU is clearly attempting to establish itself as a global human rights actor. The chapter explores the role which the EU has committed itself to in relation to the promotion of social rights and international labour standards in its CCP. In particular, it examines the EU's practice of promoting social standards through the Generalized System of Preferences ('GSP' - in its three main variants, i.e. the 'general GSP' scheme, the 'GSP +' incentive scheme, and the 'Everything but Arms' (EBA) scheme) and its bilateral and regional trade agreements. The analysis includes a critical review of how labour provisions have been incorporated into trade agreements and the various goals pursued in combination with the mechanisms employed to achieve them.

In order to better understand the politics behind these developments of integrating labour rights into common commercial policies, we need to unravel the political processes behind this push for a social dimension to trade. In 'Divided We Stand: The European Parliament's Position on Social Trade in the Post-Lisbon Era' Lore Van den Putte aims to do this, and concentrates on the political processes in the European Parliament. She starts from the observation that several ideologically opposed political actors do not quarrel significantly over the necessity of integrating labour rights considerations in trade policy instruments. Van den Putte interestingly finds that the European Parliament (EP) has shown a great interest in linking social issues to trade policy, as measured by the number of EP resolutions on this topic. What is interesting about the EP's dealings with labour rights is that it has focused more on how social norms should be included in trade agreements, rather than on why. Indeed, little to no debate in the EP has been devoted to why social norms as such should be included in EU trade agreements, which is very surprising given the wide variety of ideological positions in the EP. Social trade seems to be a taken-for-granted issue among a large majority within the EP. Van den Putte argues that while it is indeed true that the EP as a whole is strongly in favour of a social clause, different ideas lie beneath this policy consensus. These different interpretations explain the current success of the concept of social trade within the EP. While at first sight these coalitions might share the same thoughts about the 'problem', a closer look reveals 
that they have different interpretations of it, which also connects to their respective social and cognitive commitment to it. On a deeper level, the discourse on social trade reveals contradictory interpretations. Van den Putte's chapter aims to unveil the different conceptions behind the social emphasis of the EP.

Ronald C. Brown in 'Asian and US Perspectives on Labor Rights under International Trade Agreements Compared' then discusses and explores how labour rights are included in non-EU trade agreements and bilateral investment treaties. He shows that what all have in common is the central role of the International Labour Organization's core labour standards. His chapter explores, via carefully selected cases such as the US-Korea Free Trade Agreement, how the US and Asian countries engage with labour rights in free trade agreements (FTAs). This example is used as an illustration of the nature and parameters of the new US model of social dimension provisions being negotiated with labour protections. The author then turns to the Asian perspective and actually notes that this encompasses a very wide diversity of approaches and countries. He tries to identify some common threads, starting from the observation that the number of ratified FTAs involving at least one country from the region is more than 100, resulting in a "convoluted "noodle bowl" of overlapping free trade agreements', which take many different forms ranging from bilateral to mega-regional ones. The author shows that in contrast to the FTAs in which the 'Global North' countries and actors such as the EU and the US are involved, the Asian FTAs pay little attention to labour issues. This might be a temporary state which could evolve, as Brown notes in his conclusion, into a situation in which labour rights are increasingly taken on board.

Frank Hendrickx and Pieter Pecinovsky shift the focus from external trade and investment policies to broader economic policies of the EU and their impact on labour rights in the context of the new EU (austerity) initiatives. In 'EU Economic Governance and Labour Rights: Diversity and Coherence in the EU, the Council of Europe and ILO Instruments', they discuss the tension between the EU's economic policies and its commitment to fundamental labour rights. This tension not only emerges within the EU's own legal order, but also in relation to policies pursued by the Council of Europe and the ILO. Hendrickx and Pecinovsky analyse this tension by means of the concept of internal and external coherence. They argue that coherence problems exist both within the EU's legal and governance system as well as in relation to international instruments. They highlight and extensively discuss problems related to internal and external coherence. In relation to internal coherence, the authors note that, within the EU, the relationship between the economic and social dimension is 
unbalanced. As long as there is an imbalance between economic and social policies in the EU, there will remain good reasons for criticism directed at economically motivated EU measures which are designed to have a (negative) impact on labour rights and welfare systems. Concerning external coherence, the authors observe inconsistencies and contradictory outcomes from different enforcement mechanisms at the international level (the EU, Council of Europe and ILO). Given these inconsistencies, the authors raise the question of which level has the authority to induce others to correct their views or approaches. In the current situation, it seems that neither the ILO nor the Council of Europe is capable of imposing their views on the EU. Moreover, the Union's member states are bound by the ILO's conventions, the European Social Charter and the ECHR, but the $\mathrm{EU}$ is not bound by them directly. In exploring answers to this question Hendrickx and Pecinovsky assess different possibilities, including the accession of the EU to the European Convention of Human Rights and shifting from hierarchical perspectives on nested legal orders to network approaches of autonomous co-existing legal orders.

Besides a range of trade and economic policies pursued by governmental and inter-governmental actors to protect labour rights, we also observe the emergence and further development of initiatives by non-state actors. They take different forms elaborated in different contributions. The next two contributions look at either side of the "employment relation', namely unions and firms. The first contribution, 'Trade Unions and Collective Bargaining Power in Global Labor Governance' by Sigrid Koch-Baumgarten and Melanie Kryst, focuses on the action of one of the most obvious non-state actors in labour relations, namely the trade unions in the context of a shift in labour governance from the national to the international level and the emergence of new non-state actors such as labelling organizations and NGOs. Their chapter examines the importance of trade unions in this evolving context and how their corporate and economic power in collective bargaining helps to regulate, implement and monitor labour rights and labour protection in a global economy. They focus on specific actions, resources and potential power that trade unions can bring to transnational labour governance. In this context specific attention is given to International Framework Agreements (IFAs) as a key instrument used by unions. These are, according to the ILO (2007), 'instruments negotiated between a multinational enterprise and a Global Union Federation (GUF) in order to establish an ongoing relationship between the parties and ensure that the company respects the same standards in all the countries where it operates'. IFAs are based on social dialogue or collective bargaining with workers' representatives on a global or regional multinational enterprise level, and often include the four fundamental 
principles and rights at work, making specific reference to ILO conventions. These IFAs should not be regarded as substitutes for new forms of global labour governance but as a complement to them. In this way, as Koch-Baumgarten and Kryst argue, unions strengthen and complement new forms of labour governance by bringing collective bargaining power and transnational networks to the fore. They illustrate this further via case studies such as trade union regulation of the maritime industry and an analysis of the Clean Clothes Campaign (CCC), an example of NGOs cooperating with trade unions to defend labour rights transnationally.

The second contribution provides a perspective from the firm and investigates the corporate social responsibility (CSR) policies firms are developing, framed in the context of an internationally agreed upon set of labour rights and standards. The purpose of the chapter by Ruben Zandvliet and Paul van der Heijden, 'The Rapprochement of ILO Standards and CSR Mechanisms: Towards a Positive Understanding of the "Privatization" of International Labour Standards', is to examine the relevance of international labour law in the context of corporate social responsibility, and it specifically analyses the consequences of the so-called privatization of public norms. The chapter analyses to what extent international labour law, including the work of the ILO supervisory bodies, is relevant in the context of corporate social responsibility. It first analyses the use of ILO standards by other fields of public international law and notes a trend towards more reliance on ILO standards by a variety of bodies. This analysis lays the groundwork for the observation that ILO standards are globally diffusing through different mechanisms. Next, the authors turn to the interaction between international labour law and CSR and the possible privatization of international law. The authors argue that contrary to some other perspectives, privatization of public standards should not be equated with private standards that lack this public underpinning. Contemporary CSR practice shows a trend towards more complete and more specific references to international labour law. Secondly, they argue that privatization of public norms might be necessary to further strengthen their enforcement. Thirdly, they note that privatization is usually accompanied by public regulation and hence does not necessarily lead to a hollowing out or weakening of the state.

Moving away from the traditional non-state actors in employment relations, the next four chapters focus more specifically on new non-state actors involved in global labour governance. Abdul-Gafar 'Tobi' Oshodi in 'Between the Dragon's Gift and its Claws: China in Africa and the (Un) civil Fostering of ILO's Decent Work Agenda' analyses China's labour practices in Africa vis-à-vis struggles for the incorporation of the ILO's Decent Work Agenda across the continent. The chapter highlights the 
'points of exit' of African governments and the 'points of engagement' of African non-state actors in the fostering of the Decent Work Agenda in Chinese companies in Africa. With several examples, the chapter not only identifies the civil contexts of non-state points of engagement, but most importantly warns against the possibility of increased uncivil confrontations as a reaction to the exit of African governments in the prioritization of the Decent Work Agenda. The chapter illustrates the potential dangers of non-state engagement since it might 'hollow out' state-led commitments.

In 'On the Transformative Capacity of Private Fair Labour Arrangements' Ceren Pekdemir, Pieter Glasbergen and Ron Cörvers focus on the role of private labour monitoring initiatives which aim to govern global supply chains. These initiatives may be multi-stakeholder when they are partnerships that include actors from both civil society and the business domain or initiatives springing solely from civil society or the market domain. These arrangements are involved in regulatory activities that are voluntary in nature and encompass setting standards, providing training for businesses, monitoring the implementation of standards, certifying factories, and accrediting certification programmes. Many of these schemes have recently been criticized for not being very effective. After introducing these different forms of private governance, the authors engage with the debate on effectiveness and argue that the ineffectiveness of initiatives should not be understood as a consequence of individual arrangements, but as originating from some characteristics of the system of arrangements as a whole, which impairs the transformative capacity of private arrangements. The authors define transformative capacity as the ability to bring about substantial change in unfair labour practices. Their chapter provides further food for thought on the potential but also, and especially so, the limitations of private initiatives to govern labour standards.

The issue of the potential and limitations of private governance is further explored by Dennis Klink in 'Compliance Opportunities and the Effectiveness of Private Voluntary Standard Setting - Lessons from the Global Banana Industry'. He focuses on private labour governance in an agricultural sector and analyses the different adoption rates of private certification schemes. He starts from the observation that all multinational firms trading bananas have endorsed and committed themselves to various voluntary social and environmental certification systems at the central company level. These private systems often form the cornerstone of their corporate social responsibility policies. However, when comparing the adoption statistics of different banana-producing countries, Klink observes significant differences, despite the fact that these countries are 
integrated into the global supply chains of firms. This finding draws attention to the importance of domestic political conditions in individual supply-chain countries for the effectiveness of these schemes as measured by their adoption rate. Klink further elaborates on this and develops an analytical framework to better understand these domestic conditions. This framework focuses on four conditions: public business regulations; compliance culture; labour market characteristics; and education of the workforce. He applies this framework to GlobalGAP certification in two countries (Ecuador and Costa Rica) and concludes that institutional characteristics in producing countries are of key importance in understanding the effectiveness of voluntary standards.

A final contribution on non-state actors focuses on the outcomes of the Rana Plaza disaster. On 24 April 2013, a ready-made garment factory collapsed in Dhaka, Bangladesh. As an estimated 1,129 casualties were mourned in the aftermath of the Rana Plaza disaster, the debate on the need for international action was soon revived. This resulted inter alia in the Accord for Fire and Building Safety in Bangladesh, which is an independent, legally binding agreement between brands and trade unions designed to work towards a safe and healthy Bangladeshi ready-made garment industry. The contribution by Juliane Reinecke and Jimmy Donaghey, 'The "Accord for Fire and Building Safety in Bangladesh" in Response to the Rana Plaza Disaster', uses the case study of the response to Rana Plaza to examine how production and consumption-based power interact to produce private labour governance in global supply chains. They argue that the Accord is unprecedented in its binding nature and hence constitutes a very interesting case study to further analyse the potential of a specific form of private governance which focuses on safety issues. Their findings indicate how the complementarity of production and consumption-based power contributed to making an agreement binding which includes a significant number of international and brand-name firms. The research shows how the production-consumption interface may provide leverage to improve labour standards in global supply chains.

Many of these contributions show the potential of some of these initiatives, but also point to their limitations, often implicitly, or even explicitly, hinting at the importance of a strengthened multilateral approach with a stronger enforcement mechanism. This brings us back to the International Labour Organization. Indeed, throughout all the contributions the International Labour Organization plays an important role, since it provides the legal framework for the protection of labour rights which is used in these non-multilateral approaches. Founded almost a century ago in a world which differs greatly from today's, its role might change and shift in the context of these evolving governance dynamics. 
Building on the previous chapters and starting from this observation Yossi Dahan, Hanna Lerner and Faina Milman-Sivan submit proposals of what this shift might entail. The central claim in 'The International Labour Organization, Multinational Enterprises, and Shifting Conceptions of Responsibility in the Global Economy' is that the ILO should rethink its understanding of the very concept of responsibility, which currently rests on an outdated conception that is unsuited to the structure of the global economy. According to this outdated conception, the nation state is either the sole or primary agent bearing responsibility towards workers within member states' jurisdictions. As becomes clear in the other chapters in this volume, recent economic, political and legal developments across the globe have changed the context in which the ILO operates. Hence the ILO should not only allocate responsibility for workers' rights to states but also empower private non-state actors. The authors propose that the ILO adopts a novel conception of shared responsibility, which they term the labour connection model of shared responsibility. In this model, the responsibility for remedying unjust working conditions in the global labour market is borne by a complex set of agents and institutions that participate in global production, including multinational enterprises.

In a concluding chapter we assess the different contributions via the red thread of enforcement. What do we learn from the different contributions in terms of the enforcement of international labour rights? In answering this question we hope to contribute to a better understanding of how labour rights can be protected in a globalizing world.

\section{REFERENCES}

Hafner-Burton, E. (2013) Making Human Rights a Reality. Princeton: Princeton University Press.

ILO (International Labour Organization) (2007) 'International Framework Agreements: A Global Tool for Supporting Rights at Work', http://www.ilo. org/global/about-the-ilo/newsroom/news/WCMS_080723/lang--en/index.htm

ILO (International Labour Organization) (2008) ILO Declaration on Social Justice for a Fair Globalization, adopted by the International Labour Conference at its Ninety-seventh Session, Geneva, 10 June.

ILO (International Labour Organization) (2009) 'Plan of Action (2010 2016). Towards Widespread Ratification and Effective Implementation of the Governance Conventions: Labour Inspection, Employment Policy and Tripartite Consultation', adopted by the Governing Body of the International Labour Organization at its 306th Session, November.

ILO (International Labour Organization) (2013) Social Dimensions of Free Trade Agreements. Geneva: International Institute for Labour Studies and International Institute for Labour Studies. 
Kucera, D. (2001) 'Measuring Fundamental Rights at Work', Statistical Journal of the United Nations, 18: 175-186.

Kucera, D. (2002) 'Core Labour Standards and Foreign Direct Investment', International Labour Review, 141(1-2): 31-69.

Marx, A. and J. Wouters (2015) 'Competition and Cooperation in the Market of Voluntary Standards Sustainability Standards', in Delimatsis, P. (ed.) International Standardization - Law, Economics and Politics. Cambridge: Cambridge University Press.

Marx, A. and J. Wouters (forthcoming) 'Redesigning Enforcement in Private Labor Regulation: Will it Work?', International Labor Review.

Meunier, S. and K. Nicolaïdis (2006) 'The European Union as a Conflicted Trade Power', Journal of European Public Policy, 13(6): 906-925.

Mosley, L. (2011) Labor Rights and Multinational Production. Cambridge: Cambridge University Press.

Niforou, C. (2012) 'International Framework Agreements and Industrial Relations Governance: Global Rhetoric Versus Local Realities', British Journal of Industrial Relations, 50(2): 352-373.

Simmons, B. (2009) Mobilizing for Human Rights: International Law in Domestic Politics. Cambridge: Cambridge University Press.

Simmons, B. (2013) 'From Ratification to Compliance: Quantitative Evidence on the Spiral Model', in Risse, T., Ropp, S. and Sikkink, K. (eds) The Persistent Power of Human Rights: From Commitment to Compliance. Cambridge: Cambridge University Press, pp.43-59.

Vogel, D. (2005) The Market for Virtue: The Potential and Limits of Corporate Social Responsibility. Washington, DC: The Brookings Institution.

World Bank (2012) World Development Report 2013 on Jobs. Washington, DC: World Bank.

World Commission on the Social Dimension of Globalization (2004) A Fair Globalization: Creating Opportunity for All. Geneva: ILO.

Wouters, J., A. Marx, D. Geraets and B. Natens (eds) (2015) Global Governance through Trade. Cheltenham, UK and Northampton, MA, USA: Edward Elgar Publishing.

Yap, J. (2013) 'Beyond "Don't Be Evil": The European Union GSP+ Trade Preference Scheme and the Incentivisation of the Sri Lankan Garment Industry to Foster Human Rights', European Law Journal, 19(2): 293-301. 